\title{
A cross-sectional study of newborns over a 20-year period in Szeged, Hungary
}

\section{Karola Kálló, Sarolt Lehóczki, Zsuzsanna Just, Zita Gyurkovits, György Pálfi \&} Hajnalka Orvos

To cite this article: Karola Kálló, Sarolt Lehóczki, Zsuzsanna Just, Zita Gyurkovits, György Pálfi \& Hajnalka Orvos (2015) A cross-sectional study of newborns over a 20-year period in Szeged, Hungary, The Journal of Maternal-Fetal \& Neonatal Medicine, 28:5, 540-543, DOI: 10.3109/14767058.2014.924101

To link to this article: https://doi.org/10.3109/14767058.2014.924101

Accepted author version posted online: 14

May 2014.

Published online: 05 Jun 2014.

\section{Submit your article to this journal $c$}

Џ Article views: 44

Q View related articles $\sqsubset$

View Crossmark data [ᄌ 


\title{
A cross-sectional study of newborns over a 20-year period in Szeged, Hungary
}

\author{
Karola Kálló ${ }^{1}$, Sarolt Lehóczki ${ }^{1}$, Zsuzsanna Just ${ }^{1}$, Zita Gyurkovits ${ }^{2}$, György Pálfi ${ }^{1}$, and Hajnalka Orvos ${ }^{2}$ \\ ${ }^{1}$ Department of Anthropology and ${ }^{2}$ Department of Obstetrics and Gynaecology, University of Szeged, Szeged, Hungary
}

\begin{abstract}
Objective: Records of metric data of birth, serve not only the medical needs of the newborn baby, but are also indicators to assess the status of public health.

Methods: This is a retrospective study of 4946 newborns (singleton: 2508 boys and 2365 girls) born in 1989 and in 2009 at the Department of Obstetrics and Gynaecology of the University of Szeged. We aimed as to compare and map the metrical changes over 20 years, and to describe the averages of four body parameters of the normal birth weight (2500-4000 g) subgroup (3993 singleton babies) in both years. Statistical analysis was performed with SPSS 17.0.

Results: In 1989, the mean birth weight was $3223.770 \pm 559.595 \mathrm{~g}$, birth length $49.551 \pm 2.729 \mathrm{~cm}$, chest circumference $32.181 \pm 2.231 \mathrm{~cm}$, and head circumference $34.122 \pm 1.688 \mathrm{~cm}$. In 2009 , the birth weight was $3309.673 \pm 582.630 \mathrm{~g}$, birth length $49.515 \pm 2.658 \mathrm{~cm}$, chest circumference $32.736 \pm 2.392 \mathrm{~cm}$ and head circumference $33.854 \pm 1.768 \mathrm{~cm}$. The mean birth weight, chest circumference and the maximum value of birth weight have thus increased. The mean maternal age shifted to $30.21 \pm 4.863$ years, which is an increase of 3.57 years in 20 years.

Conclusion: The body parameters of newborns changed significantly between 1989 and 2009 . As underlying causes changes in eating habits and lifestyle of the mother are to be mentioned.
\end{abstract}

\section{Keywords}

Birth length, birth weight, chest circumference, developmental status, head circumference, metric data, newborn

\section{History}

Received 15 December 2013

Accepted 11 May 2014

Published online 5 June 2014

\section{Introduction}

Beyond the gestational age (GA), the body parameters of the newborn - weight, length, head and chest circumferences are necessary to determine and to judge the developmental status of a newborn.

In case these metric data are under the 10th percentile, the term "small for gestational age" (SGA), and, if sizes are above the 90th percentile, the term "large for gestational age" (LGA) are used. Based on their birth weight, babies can be divided in three groups: the large or macrosomic (above $4000 \mathrm{~g})$, the normal $(2500 \mathrm{~g}-4000 \mathrm{~g})$, and the small birth weight group (below $2500 \mathrm{~g}$ ) [1]. A comparison of these data with the growth curves also reveals an upward tendency [2].

The Hungarian birth weight and body length growth curves were set by Joubert in 1983 and 2000 - based on the data from 1973-78 and 1990-96.

Since then these weight and length standards have been used in Hungary for defining the developmental status of the newborn. Joubert also referred to the fact that the mean birth weight had risen over the two decades he studied: in 1973, the mean birth weight was $3106 \mathrm{~g}$, while it was $3230 \mathrm{~g}$ in 1996 [3].

Address for correspondence: Karola Kálló, Department of Anthropology, University of Szeged, 6701. Szeged, Pf. 660, Hungary. Fax: +36 62545711. E-mail: kallo.karola@gmail.com
Our aim was to compare the body size data of newborn babies born at the Department of Obstetrics and Gynaecology, University of Szeged in 2009 with the data of babies born in 1989.

\section{Methods}

In this study, we analysed the developmental status of newborns born in 1989 and in 2009 at the Obstetrics and Gynaecology Department, University of Szeged.

Our retrospective study is based on a database that contains the data from birth diaries, birth histories, charts, and the MedSolution database used at the University. Body size was measured by the clinical staff within 1 hour of birth. Birth weight was measured by analogue or digital scale, and body length with a tape measure and a calliper. Head circumference and chest circumference were measured with a plastic tape measure. Notes on the circumstances of the mother and the pregnancy were taken by a doctor at the time of hospitalization.

We included in the study all live singleton newborns born in 1989 and 2009, independent of the circumstances and the mode of delivery. The collection of data was also extended to premature and intrauterine growth-retarded newborns.

Statistical analysis was performed with SPSS Statistics 17.0 (SPSS Inc., Chicago, IL) and Microsoft Excel. 
The comparison of singleton birth data was carried out with the One-Way ANOVA test by gender. The subset data for babies born with normal birth weight (2500-3999 g) [4] was analysed with the Kruskal-Wallis test, in addition to the descriptive statistics. We defined the level of significance at $p<0.05$. The reported values are means \pm SD. The number of cases is indicated in the tables.

\section{Results}

In 1989, a total of 2119 babies were born, 25\% fewer than in 2009. Out of these, 2045 were singleton birth babies of whom 1715 (80.93\% of all, 871 boys and 844 girls) weighed between $2500 \mathrm{~g}$ and $4000 \mathrm{~g}$. In 2009, 2827 newborns were born (1443 boys and 1384 girls). 2679 newborns, 94.76\% of all babies, were singleton births in 2009. Out of these, 2278 (80.58\% of the total) were born with normal birth weight [5].

\section{Distribution of singleton newborns by gender, birth weight and gestational age}

Distribution data for all singleton babies born in 1989 and in 2009 are contained in Table 1. In the year 1989, 1864 babies were born above $2500 \mathrm{~g}$; from among this group, 149 babies were macrosomic. Twenty years later, 2480 newborn babies $(87.72 \%$ of the total, 1275 boys and 1205 girls) weighed above $2500 \mathrm{~g}$; in 2009, out of these, 202 (7.14\% of the total, 141 boys, 61 girls) were macrosomic. Furthermore, 2278 babies ( $80.58 \%$ of the total, 1134 boys and 1144 girls) were born with normal birth weight.

The rate of SGA decreased among both girls and boys over the 20 years in question, and the rate of macrosomia increased among boys, but decreased among girls in our sample.

Regarding GA, in 2009, 8.545\% (229) of babies were born preterm (before the 37th gestational week). In 1989, this number was $10.532 \%$ (212 babies).

The rate of mature newborns has increased $(89.220 \%$ versus $91.418 \%$ ) over the 20 years. The rate of post-term babies (born after 41 weeks of gestation) has also decreased (from $5 \%$ to $1 \%$ ).

Table 1. Distribution of newborns by gender and birth weight in 1989 and in 2009 ( $\mathrm{N}=$ number of cases).

\begin{tabular}{lccc}
\hline Birth weight $(\mathrm{g})$ & & 1989 & 2009 \\
\hline Boy & & & \\
$<2500$ & $\mathrm{~N}$ & 97 & 101 \\
& \% of year & 9.108 & 7.340 \\
$2500-4000$ & $\mathrm{~N}$ & 871 & 1134 \\
& \% of year & 81.784 & 82.413 \\
$>4000$ & $\mathrm{~N}$ & 97 & 141 \\
& \% of year & 9.108 & 10.247 \\
Total & $\mathrm{N}$ & 1065 & 1376 \\
& \% of year & 100 & 100 \\
Girl & & & \\
$<2500$ & $\mathrm{~N}$ & 84 & 98 \\
& \% of year & 8.571 & 7.521 \\
$2500-4000$ & $\mathrm{~N}$ & 844 & 1144 \\
& \% of year & 86.122 & 87.797 \\
$>4000$ & $\mathrm{~N}$ & 52 & 61 \\
& \% of year & 5.306 & 4.682 \\
Total & $\mathrm{N}$ & 980 & 1303 \\
& \% of year & 100 & 100 \\
\hline
\end{tabular}

\section{Means of body size}

We summarise the body size and gestational and maternal age for babies of single birth in both years: Table 2 demonstrates the rates of change over 20 years, and shows the significant values of each body size.

All body parameters of the boys are bigger than those of the girls, and these differences are significant $(p<0.05)$. Table 2 shows that the mean birth weight increased by an average of $85.95 \mathrm{~g}, 97.879 \mathrm{~g}$ among boys and by $74.599 \mathrm{~g}$ among girls. The birth weight maximum of boys increased dramatically; the biggest baby in 2009 weighed $5.500 \mathrm{~g}$, but in 1989 this was only 4960. Meanwhile, the biggest girl in 2009 was only $180 \mathrm{~g}$ bigger than the biggest girl in 1989. The smallest babies were also smaller in 2009 than in 1989, but this can be explained with changes in the Hungarian medical protocol; since 1998, babies born at or after the 24th week of gestation are considered premature, and not only those born after the 27th gestational week, as was previously the case.

According to the WHO birth standards (2006) the mean birth weight of boys is $3.3464 \pm 0.146 \mathrm{~kg}$, and the mean birth weight of girls $3.2322 \pm 0.141 \mathrm{~kg}$ [6]. In our sample, the mean birth weight is slightly higher and means fall in between the 50th and the 75th percentile.

Interestingly, the gestational age of girls is higher in both years, which means that girls stayed longer in the uterus than boys: 0.116 weeks (19.488 hours) in 1989 and 0.2 weeks (33.6 hours) in 2009. Both differences are significant $(p<0.05)$. In 1989 , the mean gestational age of newborns was $38.506 \pm 1.859$ weeks. The mean gestational age of newborns in 2009 was $38.50 \pm 1.945$ weeks, and hence it did not change. We compared the birth weight with the data shown for the 38th gestational week in the reference tables of Joubert [3]. The data for both genders falls between the 50th and the 75th percentile in both years.

Birth length has not changed over the 20 years in question when comparing the normal subset group of the two years. For both girls and boys, the mean values of 2009 fall between the 25th and the 50th percentile of the 38th gestational week in Joubert's Hungarian reference table [3]. Comparing the mean birth length (boys $49.80 \pm 2.794 \mathrm{~cm}$, girls $49.21 \pm 2.474 \mathrm{~cm}$ ) to the WHO standards (2006) [6] (boys $49.88 \pm 1.8931 \mathrm{~cm}$ and girls $49.14 \pm 1.8627 \mathrm{~cm}$ ) we observed that the value for male newborns born in 2009 in Szeged is lower, falling between the 25th and 50th percentile, but for girls it exceeds this value and falls between the 50th and 75th percentile.

Table 2 shows that over the 20 years chest circumference increased significantly, by $0.612 \mathrm{~cm}$ in the subgroup boys, and by $0.495 \mathrm{~cm}$ in the girls, or by an average of $0.559 \mathrm{~cm}$ in total. An increase in chest circumference is evident in all subgroups of our sample (see Figure 1).

On the other hand, the head circumference data showed a downward tendency. In 2009, the mean head circumference of boys was $0.312 \mathrm{~cm}$ smaller, and that of girls $0.218 \mathrm{~cm}$ smaller, compared to 20 years before. Means for both genders are lower than the WHO standard (2007) [7], which is $34.46 \pm 1.270 \mathrm{~cm}$ for boys and $33.87 \pm 1.184 \mathrm{~cm}$ for girls.

Maternal age increased over the 20 years (Table 2). In 1989, maternal age of boys and girls differed by almost half a year ( 0.429 years), but in 2009 the two values were very 
Table 2. Main data of singleton newborns born in 1989 and in 2009 in Szeged, Hungary.

\begin{tabular}{|c|c|c|c|c|c|c|}
\hline & $\begin{array}{l}\text { Gestational age } \\
\text { (week) }\end{array}$ & $\begin{array}{c}\text { Birth } \\
\text { weight }(\mathrm{g})\end{array}$ & $\begin{array}{c}\text { Birth } \\
\text { length }(\mathrm{cm})\end{array}$ & $\begin{array}{c}\text { Chest } \\
\text { circumference }(\mathrm{cm})\end{array}$ & $\begin{array}{c}\text { Head } \\
\text { circumference }(\mathrm{cm})\end{array}$ & $\begin{array}{r}\text { Maternal } \\
\text { age (year) }\end{array}$ \\
\hline \multicolumn{7}{|l|}{1989} \\
\hline \multicolumn{7}{|l|}{ Boy } \\
\hline Mean & 38.450 & 3267.671 & 49.877 & 32.278 & 34.392 & 26.838 \\
\hline $\mathrm{N}$ & 1048 & 1065 & 1061 & 1049 & 1060 & 1065 \\
\hline SD & 1.895 & 574.128 & 2.788 & 2.248 & 1.718 & 5.342 \\
\hline \multicolumn{7}{|l|}{ Girl } \\
\hline Mean & 38.566 & 3176.061 & 49.197 & 32.075 & 33.828 & 26.409 \\
\hline $\mathrm{N}$ & 965 & 980 & 979 & 970 & 976 & 979 \\
\hline SD & 1.819 & 539.615 & 2.619 & 2.208 & 1.605 & 5.379 \\
\hline \multicolumn{7}{|l|}{ Total } \\
\hline Mean & 38.506 & 3223.770 & 49.551 & 32.181 & 34.122 & 26.632 \\
\hline $\mathrm{N}$ & 2013 & 2045 & 2040 & 2019 & 2036 & 2044 \\
\hline SD & 1.859 & 559.595 & 2.729 & 2.231 & 1.688 & 5.362 \\
\hline \multicolumn{7}{|l|}{2009} \\
\hline \multicolumn{7}{|l|}{ Boy } \\
\hline Mean & 38.405 & 3365.552 & 49.802 & 32.892 & 34.082 & 30.225 \\
\hline $\mathrm{N}$ & 1376 & 1376 & 1367 & 1363 & 1364 & 1373 \\
\hline SD & 2.084 & 622.784 & 2.794 & 2.511 & 1.841 & 4.827 \\
\hline \multicolumn{7}{|l|}{ Girl } \\
\hline Mean & 38.602 & 3250.664 & 49.214 & 32.572 & 33.615 & 30.201 \\
\hline $\mathrm{N}$ & 1303 & 1303 & 1301 & 1297 & 1298 & 1301 \\
\hline SD & 1.783 & 530.865 & 2.474 & 2.250 & 1.654 & 4.903 \\
\hline \multicolumn{7}{|l|}{ Total } \\
\hline Mean & 38.501 & 3309.673 & 49.515 & 32.736 & 33.854 & 30.213 \\
\hline $\mathrm{N}$ & 2679 & 2679 & 2668 & 2660 & 2662 & 2674 \\
\hline SD & 1.945 & 582.630 & 2.658 & 2.392 & 1.768 & 4.863 \\
\hline
\end{tabular}

similar (30.23 years versus 30.20 years). However, the maternal age had advanced to $30.21 \pm 4.863$ years by 2009 , which is 3.57 years more than in 1989 .

\section{Discussion}

Body size at birth has great importance in newborn care because this data allows conclusions regarding the level of development and also regarding the presence of any underlying disease. Furthermore, this data also provides support for assessing the state of public health and in demographic studies. In Hungary, the infant mortality rate (infants per 1000 live births) was 18 in the year 1989, which by 2009 had decreased to 6 [8].

In our study, we observed a change in body sizes over 20 years. The mean body weight and chest circumference and the maximums of birth weight increased, while body length and head circumference decreased. The ratio of macrosomia increased slightly (from $7.28 \%$ to $7.53 \%$ ), but it is still lower than the Hungarian average (9\%) [9].

By 2009, the average age for women giving birth had gone up to about 30 years in Szeged, which is an increase of more than 3.5 years over the period. Kapitány and Spéder note that the advanced age of pregnant women could be explained by changes in relationships, the longer time spent in education, and the quest for financial security. Individual goals and interests became primarily important [10]. After the change of regime in 1989 in Hungary, pregnancy thus shifted to the late 20 s and early 30 s, just as in developed countries.

The shift in our sample could also be due to the transformation of the Hungarian system of higher education, and also to the fact that Szeged is a typical university city women in their 20 s are at the beginning of their university studies and job search, and establishing a livelihood has become a priority.

Kapitány and Spéder claim that the Hungarian fertility rate was among the lowest in Europe and in the world in 2009 [10]. As in other former socialist countries [11], a typical decrease in population occurred in Hungary, which has not changed since then [12]. At the Obstetrics Clinic in Szeged, records show a growth in the number of births from 1989 to 2009, but this is due to the fact that in 1989 there were two hospitals in the city where babies were being delivered, so that the database from 1989 does not contain all the babies born in Szeged in that year. In 2009, there was a merger of the two hospitals, so that the 2009 database already contains all the babies born in that year.

\section{Conclusion}

Our paper is unique in studying the body metric status of newborns over a 20-year period in Szeged. The city is the regional centre of the Southern Hungarian Region and the seat of Csongrád county. Therefore, its birth statistics jurisdiction extends beyond the perimeter of the city.

Our findings support the presence of a secular trend that influences the acceleration in Hungary, which can be also seen in the changing of body metric parameters of newborns over the 20 years in question. The increasing averages of metric data for newborns are linked to the improvement of maternal lifestyles, and this can be described as a fast change [13]. This may also result in the need for the creation of new reference tables.

\section{Acknowledgements}

We thank Prof. Attila Pál for his permission for data collection and Dr. Judit Bakki for her help in data collection. 


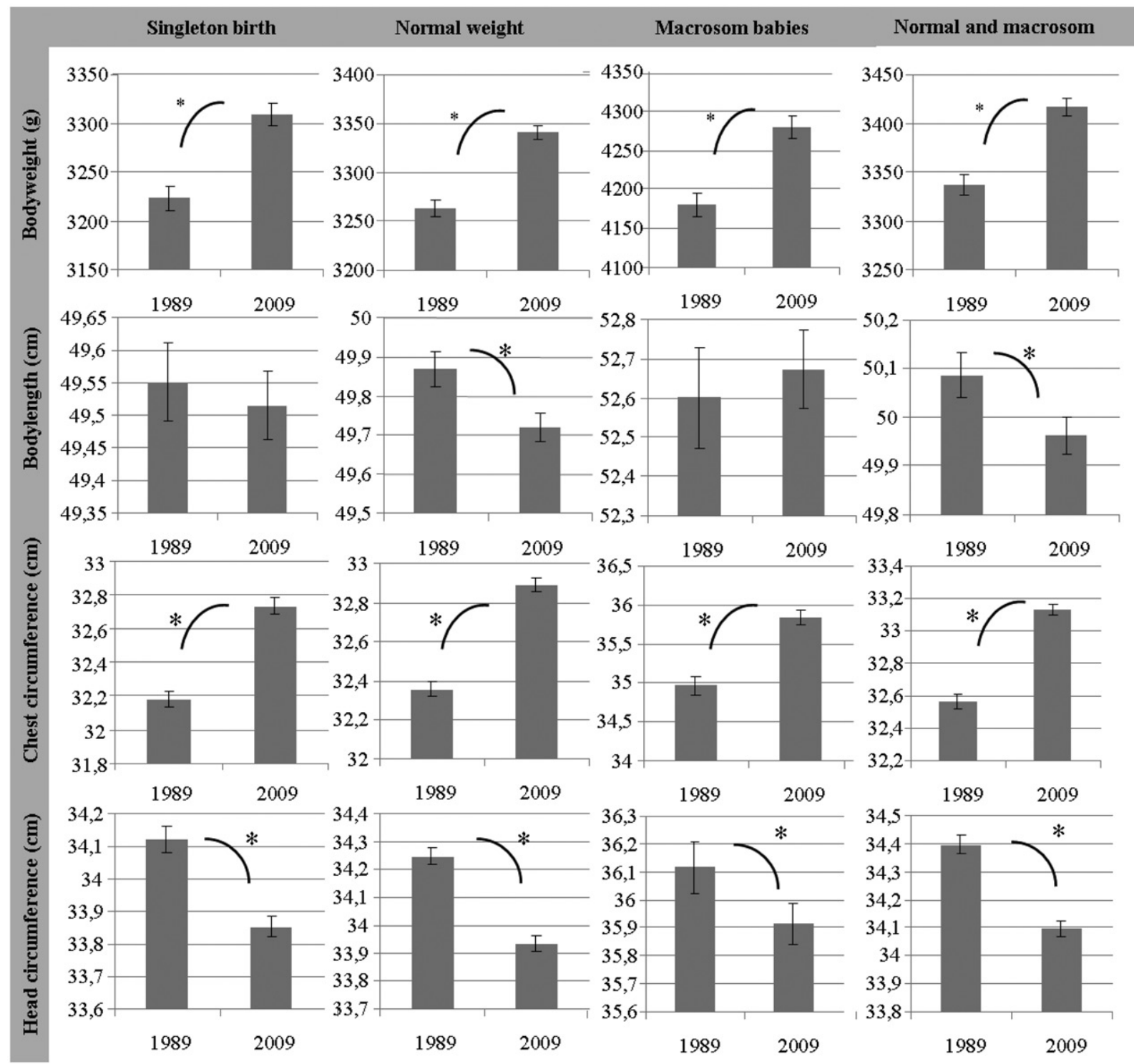

Figure 1. Comparison of the four measured bodysizes in the different subset of data in the two studied year 1989 and 2009 . We found significant increase in bodyweight and in chest circumference in singleton birth, but also comparing both the normal bodyweight, and the macrosom group, as well by combination of normal and macrosom subset of data. Mark *Shows the level of significance set by $p<0.05$.

\section{Declaration of interest}

The authors report no declarations of interest.

\section{References}

1. Battaglia FC, Lubchenco LO. A practical classification of newborn infants by weight and gestational age. J Pediatr 1967;71: 159-63.

2. Figueras F, Figueras J, Meler E, et al. Customised birthweight standards accurately predict perinatal morbidity. Arch Dis Child Fetal Neonatal Ed 2007;92:F277-80.

3. Joubert K. Magyar születéskori testtömeg- és testhossz-standardok az 1990-96. évi országos élveszületési adatok alapján. Magyar Nö orvosok Lapja 2000;63:155-63.

4. Lalys L, Pineau JC, Guihard-Costa AM. Small and large foetuses: Identification and estimation of foetal weight at delivery from thirdtrimester ultrasound data. Early Hum Dev 2010;86:753-7.

5. Gyurkovits Z, Kallo K, Bakki J, et al. Neonatal outcome of macrosomic infants: an analysis of a two-year period. Eur J Obstet Gynecol Reprod Biol 2011;159:289-92.

6. WHO MGRSG. WHO Child Growth Standards: Length/height-forage, weight-for-age, weight-for-length, weight-for-height and body mass index-for-age: Methods and development. Geneva: World
Health Organization; 2006. Available from: http://www.who.int/ childgrowth/standards/technical_report/en/ [last accessed 17 May 2013].

7. WHO MGRSG. 2007 WHO Child Growth Standards: Head circumference-for-age, arm circumference-for-age, triceps skinfold-for-age and subscapular skinfold-for-age: Methods and development. Geneva: World Health Organization; 2007. Available from: http://www.who.int/childgrowth/standards/second_set/technical_report_2/en/ [last accessed 17 May 2013].

8. UN I-aGfCME. Infant mortality rate is the number of infants dying before reaching one year of age, per 1000 live births in a given year. World Wide Web: United Nations; 2011.

9. Bánhidy F, Pál A. A szülészet-nő gyógyászat egyetemi tankönyve Budapest: Medicina Kiadó Zrt 2012.

10. Kapitány B, Spéder Z. Gyermekvállalás. Hungarian Central Sttistical Office, Demographic Research Institute; 2009. 29-40 p.

11. Sagan A, Panteli D, Borkowski W, et al. Poland health system review. Health Syst Transit 2011;13:1-193.

12. Vlassov VV. Prevention and social constructivism. Eur J Public Health 2009;19:567.

13. Rooth G. Increase in birthweight: a unique biological event and an obstetrical problem. Eur J Obstet Gynecol Reprod Biol 2003;106: 86-7. 